\title{
THE LAND GRANT TO THE CALGARY AND EDMONTON RAILWAY COMPANY
}

\author{
KIRK N. LAMBRECHT and JOHN GILPIN
}

This article uses archival records to study the litigation surrounding the land grant to the Calgary and Edmonton Railway, which was the first railway to approach Edmonton and Fort Macleod. The Dominion of Canada granted 1,888,448 acres of land in Alberta to the Calgary and Edmonton Railway Company to assist in financing construction of the line and also attempted to shield these lands from local taxation. The $C \& E$ went to Court to obtain mines and minerals in the land grant and in an effort to avoid local taxation. The authors analyze these cases and outline the implications of the decisions, particularly in the creation of private mineral title in western Canada.
Par le biais de documents d'archives, le présent article examine le litige relatif aux concessions de terre accordées à la Calgary and Edmonton Railway, la première société de chemin de fer à construit une voie ferrée en direction d'Edmonton et de Fort Macleod. Le gouvernement du Dominion du Canada avait concédé à cette société un territoire d'une superficie de 1888448 acres afin de l'aider à financer la construction de la voie ferrée et de la soustraire à toute imposition locale. La société $C$ \& intenta des actions en justice afin de revendiquer les mines et minéraux qui se trouvaient sur son territoire et pour éviter toute imposition locale. Les auteurs analysent ces décisions judiciaires, et en décrivent conséquences, plus particulièrement en ce qui a trait à la création de concessions minières privées dans l'Ouest du Canada.

\section{TABLE OF CONTENTS}

I. INTRODUCTION $\ldots \ldots \ldots \ldots \ldots \ldots \ldots \ldots \ldots \ldots \ldots 71$

II. DOMINION RAILWAY LAND SUBSIDY

POLICY AND THE $C \&$ E $\ldots \ldots \ldots \ldots \ldots \ldots \ldots \ldots$

III. MINES AND MINERALS $\ldots \ldots \ldots \ldots \ldots \ldots \ldots \ldots \ldots$

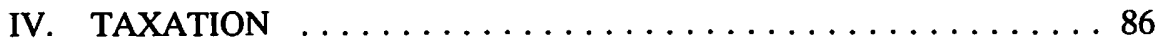

V. CONCLUSION $\ldots \ldots \ldots \ldots \ldots \ldots \ldots \ldots \ldots \ldots \ldots \ldots \ldots \ldots \ldots$

\section{INTRODUCTION}

The formation of companies by private or special Act of Parliament grew out of the canal-construction movement, a movement which followed closely on Brindley's success in the construction of the Bridgewater Canal under the Acts obtained in 1759 and 1760 by the Duke of Bridgewater... A

The views expressed in this essay, and any errors of fact or interpretation, are those of the authors. Kirk N. Lambrecht, B.A., LL.B. is a lawyer in Edmonton and the author of The Administration of Dominion Lands, 1870-1930 (Canadian Plains Research Center, University of Regina). Dr. John Gilpin, Ph.D. has lectured in Canadian History at the University of Lethbridge and the University of Saskatoon. His publications include "Urban Land Speculation in the Development of Strathcona (South Edmonton) 1891-1912" in The Developing West: Essays on Canadian History in Honour of Lewis H. Thomas (University of Alberta). The authors would like to thank G.A. Fiegal, secretary of the Calgary and Edmonton Railway Company, for providing information which could not be located in archival records. 
considerable number of canal companies were so constituted, but it was not until the great movement set in for the construction of railways - inaugurated by the Stockton and Darlington Act of 1821 - that companies constituted under special acts began to multiply.

Palmer Company Law (5th ed., 1905)

Between 1890 and 1893 the Calgary and Edmonton Railway Company (C \& E) constructed a broad gauge railway line running from a point near Fort Macleod, in the ranching frontier of the southern Alberta, to the south bank of the North Saskatchewan River opposite Edmonton, in the agricultural frontier of central Alberta. At that time the District of Alberta, North West Territories, had only two railway lines. The Canadian Pacific Railway (CPR) broad gauge main line ran through Medicine Hat, Calgary and Banff on its way to Vancouver. The North Western Coal and Navigation Company operated a narrow track line which linked the company coal mines at Lethbridge to the CPR main line at Dunmore, near Medicine Hat. By connecting with the CPR main line at Calgary and creating townsites along its line, including Strathcona, Red Deer and Wetaskiwin, the C \& E opened central Alberta to settlement, facilitated transportation to the commercial ranches south of Calgary and created the urban geography so familiar in Alberta today.

The contribution of the $C \& E$ to the development of the law is equally significant. Land grants and tax shelters were central components of the federal railway land grant system of the day. Federal subsidies to the $C \& E$ were similar in form to the subsidies given to other railway companies after the CPR main line subsidy. When the $C \& E$ went to litigation in order to obtain mineral rights in its land subsidy, and in an effort to avoid local taxation of the subsidy, the judicial decisions which resulted were profoundly important to the operation of general federal policy. This essay examines two cases involving the $\mathrm{C} \& \mathrm{E}$ which had far reaching implications for the legal history of western Canada.

Parliament supported the construction of the $C \& E$ with a land subsidy of 6400 acres per mile of rail line constructed, and with a form of shelter from local taxation. During debate on the subsidy legislation before the House of Commons Prime Minister Sir John A. Macdonald made it clear that in his view this assistance was necessary in order for the organizers of the $C \& E$ to obtain the financing necessary to construct the line. ${ }^{1}$ In all the $C \&$ E built 295.07 miles of line and received a land subsidy of $1,888,448$ acres from the government of the Dominion of Canada, all of which was located in Alberta. The C \& $\mathrm{E}$ entitlement to this land was earned as the northern and southern branches of the line were completed. ${ }^{2}$

Canada, House of Commons, Hansard (May 5, 1890) at 4420-21

For the northern branch of the C \& E, from Calgary to the North Saskatchewan River opposite Edmonton, formal government approval was given by Order in Council September 5, 1891 P.C. 2114. At that time the $C \& E$ became entitled to a land subsidy of $1,216,000$ acres calculated at the rate of 6,400 acres for each of the 190 miles constructed. For the southern branch of the C \& E, from Calgary to a point near Fort Macleod, formal government approval of the first fifty miles was issued by Order in Council January 8, 1892 P.C. 22. See Orders in Council of the Dept. of the Interior 
Federal support to the $C \& E$ was one example of general Dominion policy. Between 1881 and 1896 Parliament alienated more than thirty million acres of public lands in western Canada through legislated subsidies to railway companies. The CPR received over eighteen million acres of public lands to assist in financing and building its main line and several extensions of the main line. Smaller railway companies incorporated by a private Act of Parliament were also active, building additional rail lines and receiving additional subsidies of public lands. The $C \& E$ was one of these smaller railway companies, incorporated by An Act to Incorporate the Calgary and Edmonton Railway Company which received royal assent on April 24, 1890. ${ }^{3}$

Federal support for the C \& E was authorized by An Act to authorize the granting of subsidies in Land to certain Railway Companies. ${ }^{4}$ Section 2 of the statute defined the land subsidy and the tax shelter:

The said grants ... may be made in aid of the construction of the said railways ... and ... the said grants shall be free grants, subject only to the payment by the grantees of the cost of survey of the lands and incidental expenses at the rate of ten cents per acre in cash on the issue of the patents therefore.

Patent for the Crown lands making up the subsidy would not issue from the Dominion until survey fees and incidental expenses had been paid, a matter within the discretion of the $\mathrm{C} \& \mathrm{E}$. Since unpatented federal land could not be taxed by local government the $\mathrm{C}$ \& E could attempt to avoid taxation on the subsidy lands until a moment of its choice by the simple expedient of deferring payment of survey fees.

The syndicate of businessmen who organized the $C \& \mathrm{E}$ went to litigation with the Dominion, asserting that the entire railway land subsidy, 1,888,448 acres, should include mines and minerals. The Calgary and Edmonton Railway Company and Another v. The $\mathrm{King}^{5}$ held in favour of the syndicate. The ratio of the case extended beyond the C \& E to include all other legislated federal railway land subsidies in Western Canada after 1887. Mineral titles in millions of acres of lands in Western Canada were transferred from public to private ownership as a direct result of this decision.

The syndicate also attempted to avoid taxation of the C \& E lands. The Calgary and Edmonton Land Company v. Attorney General for Alberta ${ }^{6}$ determined that land reserved for the C \& E subsidy could be taxed by local government even though patent had not

(Ottawa: The Dept. of the Interior, (No. 14) 1892) at 29 [hereinafter Orders in Council]. For this fifty miles the $C \& E$ became entitled to an additional 320,000 acres of its land subsidy. The remaining portion of the southern branch was completed in 1892 and Government acceptance was issued by Order in Council December 7, 1892 P.C. 3067. See Orders in Council, ibid. (No. 14) 1892 at 643. The $C \& E$ was then entitled to receive the remainder of its land subsidy.

3 Statules of Canada, (1890) 53 Vict. c. 84.

$4 \quad$ Ibid. at c. 4.

$5 \quad$ [1904] A.C. 765 (J.C.P.C.).

$6 \quad$ (1911), 45 S.C.R. 170. 
issued from the federal Crown. The decision was immediately recognized in constitutional law as a leading case in taxation. ${ }^{7}$

To complete this study a variety of archival materials were consulted. The Provincial Archives of Alberta have files from the Attorney General's Department of Alberta relating to taxation of the $C \&$ E lands. Judicial records of the proceedings before the Alberta courts are also held by the Provincial Archives. For the proceedings before the Judicial Committee of the Privy Council in The Calgary and Edmonton Railway Company and Another v. The King the Privy Council Office in London provided the Case for the Appellants and the Respondents, and the Record of Proceedings. The National Archives of Canada provided similar materials for the proceedings before the Supreme Court of Canada in that case. Parliamentary materials include the statutes and regulations applying to the Calgary and Edmonton Railway, the Debates of the House of Commons and the Sessional Papers. Background materials are held in the Glenbow Alberta Institute Archives and the University of Alberta Archives. Returns of the Calgary and Edmonton Land Company required by the Companies Act of England are in the Public Records Office at Kew Gardens in London. The Calgary and Edmonton Railway Company itself (since 1903 a wholly owned subsidiary of Canadian Pacific Railway) kindly provided the authors with additional background information which could not otherwise be located through archival research.

\title{
II. DOMINION RAILWAY LAND SUBSIDY POLICY AND THE C \& E
}

\begin{abstract}
The last of the statutory railway land grants were made to the Pipestone Extension of the C.P.R. and the Saskatchewan and Western Railway on July 23, 1894 (57-58 Vict. c. 6). The Liberal government which took office in 1896 not only discontinued the practice but publically disavowed the policy of land subsidies in aid of railway construction. ... There was one reason, perhaps, more important than 'policy' for terminating land subsidies ... There would soon be no more land grants to give ... The ruthless scramble for eligible land reserves was in itself a sign that the supply of odd-numbered sections of lands 'fairly fit for settlement' was nearing depletion, while vast areas already 'earned' or in process of being 'earned' by railway construction remained to be located."
\end{abstract}

Chester Martin, "Dominion Lands" Policy p. 96

In 1881 An Act Respecting the Canadian Pacific Railway ${ }^{8}$ gave form to Dominion railway land subsidy policy. This legislation supported construction of the first transcontinental railway in Canada, the CPR main line through Western Canada. Under the statute the CPR received a potential land subsidy of 25 million acres ${ }^{9}$ all of which was to be "fairly fit for settlement" and exempt from taxation for twenty years "after the

W.H.P. Clement The Law of the Canadian Constitution (Toronto: Carswell, 1916) at 644; A.S. Abel and John I. Laskin, eds., Laskin's Canadian Constitutional Law 4th ed. (Toronto: Carswell, 1975) at 743.

8 Statutes of Canada, (188I) 44 Vict. c. 1.

$4 \quad$ For a variety of reasons, primarily related to financing its line, the CPR agreed to accept somewhat less than this total. See: C. Martin, "Dominion Lands" Policy (1938; reprinted Toronto: McClelland \& Stewart, 1973) at 49. 
grant thereof from the Crown. ${ }^{10}$ The land subsidies authorized by this statute, and by subsequent railway statutes, were taken from public lands in those areas which now constitute the prairie provinces.

Between 1881 and 1894, a variety of railway companies proposed additional lines and obtained additional federal support to extend the rail network in Western Canada. Federal support for these lines was expressed in separate legislation. ${ }^{11}$ These statutes offered a fixed land subsidy, usually 6400 acres of land per mile of rail constructed. Although the express twenty year tax exemption granted to the CPR for its main line subsidy was not repeated, subsequent legislation attempted to offer a form of tax shelter through a separate mechanism: delay in issue of patent from the Crown until payment of survey and incidental expenses by the railway.

Land necessary for these railway subsidies was, generally speaking, found in the odd numbered sections in surveyed townships throughout the prairies (other than sections 11 and 29, which were reserved as school lands). Under the Dominion Lands Regulations of $1881,{ }^{12}$ the odd numbered sections in each surveyed township for twenty four miles on either side of the CPR main line ["the main line reserve" or "the 48 mile belt"] was reserved to satisfy the $25,000,000$ acre CPR main line subsidy. Odd numbered sections in surveyed townships beyond the main line reserve were also be set aside or reserved by Order in Council to satisfy federal land subsidy obligations to the CPR and to other railway companies.

Each railway company became entitled to its land subsidy by constructing its rail line to a standard which was satisfactory to railway engineers employed by the Dominion government. The railways did not, however, usually receive patents for the land subsidy at that time. The Dominion government set aside "land reserves" from which the railways could "select" or "locate" enough land which was "fairly fit for settlement" so as to make

Supra note 8, ss. 11 and 16 of the schedule.

Virtually identical forms of expression were used in the following statutes, all of which authorized the "free grant" of subsidies in land to railways:

(1885) 48-49 Vict. c. 60: NW Coal \& Navigation Co.; Manitoba \& SW

Colonization RR. Co.; Manitoba \& NW Railway Co.; Qu'Appelle, Long Lake \&

Saskatchewan RR and Steamboat Co.

(1886) 49 Vict. c. 11: NW Central RR. Co.; Manitoba \& NW RR. Co; Wood

Mountain \& Qu'Appelle RR. Co.

(1887) 50-51 Vict. c. 24: Alberta \& Athabasca RR. Co.; Qu'Appelle, Long Lake \&

Saskatchewan RR. Co.; Medicine Hat RR. \& Coal Co.

(1889) 52 Vict. c. 4: NW Coal \& Navigation Co.; Red Deer Valley RR \& Coal Co.; NW Railway Co. of Canada; Lake Manitoba RR \& Canal Co.

(1890) 53 Vict. c. 4: C \& E RR Co.; CPR Souris branch; Brandon \& SW RR

Co.; Lac Seul RR Co.; NW Coal \& Navigation Co.; Lake Manitoba RR \&

Canal Co.; Manitoba \& SE RR Co.

(1891) 54-55 Vict. c. 10: CPR Souris branch; Manitoba \& SW Colonization

RR. Co.

(1894) 57-58 Vict. c. 6: CPR Pipestone branch; Rocky Mountain RR \& Coal

Co.; Brandon \& SW RR. Co.; Saskatchewan \& W. RR Co.

Order in Council December 23, 1881 P.C. 1710. See Orders in Council, supra note 2 (No. 3, 1881) at 805 . 
up each complete land subsidy. Crown lands reserved for this purpose were closed to settlement. Settlers could neither enter the lands for homestead purposes nor purchase these lands until the railways had obtained patents for the lands within the reserve and were willing to market the lands so patented.

The railways would inspect the Crown lands within the land reserves and select those odd numbered sections which were considered to be fairly fit for settlement. The lists of lands selected by the railways would be sent to the Dominion government for review. If approved, the Dominion would issue an Order in Council identifying the specific sections which each individual railway had selected to make up its subsidy. ${ }^{13}$ Patents for lands selected by the railways and approved by the Dominion were issued only after the railway or its assignees applied for patent and paid the costs of survey.

The general scheme of the federal railway land subsidy system, therefore, involved legislation authorizing the subsidy, orders in council creating land reserves to satisfy the subsidy, orders in council identifying lands within the reserves which the railways had selected as being fairly fit for settlement, and the issuing of patent for the land by the Crown. Delay could arise at any stage of the process. The date of the patent for the land could be deferred by a delay in building the railway, in setting aside the land reserve, in selecting lands within the reserve which were fairly fit for settlement or in paying the costs of survey for lands which were selected. Cumulatively these deferrals could lead to a period of years, often more than a decade, between the construction of a railway line (at which time the railway became entitled to its subsidy) and the issue of patent for the land subsidy associated with the line. Not until 1908 was the Dominion government finally able to compel the railway companies to complete the selection of their land subsidies.

These general features of the federal railway land subsidy system can be seen in operation in the case of the $C \& E$. The $C \& E$ was entitled to begin selection of its entire land subsidy by 1892 but deliberately delayed selection. More than a decade passed before the $C \&$ E finally selected all of the lands which actually made up the subsidy and more time passed after that before the survey fees were paid for many of those lands which were selected. The reasons for this are typical. The syndicate of businessmen which controlled the C \& E itself, and which also controlled the land subsidy through the Calgary and Edmonton Land Company, ${ }^{14}$ intended to reap its profit from land sales. Unfortunately a substantial market for the land did not develop until the first decades of the twentieth century. A few lands were sold during the 1890s, largely to ranchers; but substantial demand did not exist until large scale immigration to Western Canada after

While the vast majority of subsidy lands were odd numbered sections, some even numbered sections and some entire townships were selected by the railways and approved by the Dominion.

Shortly after the incorporation of the $C$ \& $E$ the land subsidy was assigned from the $C$ \& $E$ to a British company, the Calgary and Edmonton Land Company. Several of the directors of the $C \& E$ were also directors of the Calgary and Edmonton Land Company. 
1900 created agricultural communities throughout Alberta. ${ }^{15}$ Until a market for the land existed there was no reason for the syndicate to obtain patents for the land.

The general location of the land subsidy to the $\mathrm{C} \& \mathrm{E}$ was fixed by Order in Council on June $27,1890 .^{16}$ The land subsidy was to be made up of unoccupied odd-numbered sections of unpatented Crown land "within 22 miles of the line of railway on each side thereof, in so far as practicable without interfering with any previous grants or reserves." Any deficiency in this area could be made up from any available lands in the North West Territories in the discretion of the Governor in Council.

It was not possible for the $C \& E$ to select its land subsidy on either side of the $C \&$ $E$ line for the full distance between Calgary and Edmonton because the CPR had a large land reserve in this area commencing near Innisfail and extending northward to Edmonton. The CPR had persuaded the Dominion to create four large land reserves, in addition to its main line reserve, from which it would be entitled to select lands which were fairly fit for settlement. One of these large CPR reserves was located between the 52nd and 54th degrees latitude and between 104 and 116 degrees longitude. ${ }^{17}$ The southern boundary of this reserve was near Innisfail. In 1890 the odd numbered sections of Dominion lands in this block could not be granted to the C \& $E$ because they were reserved for selection by the CPR.

The undoubted quality of the agricultural land in this CPR reserve was mentioned during the Parliamentary debate on the land subsidy to the C \& E. One Member of Parliament observed: "[i]f there is any portion of that North-West country that we ought to develop by railway enterprises, it is that portion from Calgary to Edmonton.... nearly the best portion of the North-West." ${ }^{18}$ Opening railway access to the land in this CPR reserve was one of the main advantages offered by the construction of the $C \& E$. The CPR did not want to surrender its lands in this area. Rather it wanted to operate over the C \& E line to open this area of its lands to settlement.

The C \& E therefore had to look to the lands south of Calgary to make up its land subsidy, an area containing many large cattle ranches. In 1882, many large grazing leases had been issued for this area by the Dominion government. ${ }^{19}$ The southern extension of the $\mathrm{C} \& \mathrm{E}$ line to Fort Macleod offered the prospect of improved access to rail communications for some of these ranches. The value of this development was also recognized in the Parliamentary debates on the C \& E subsidy: ${ }^{20}$

See for example A.F.J. Artibise, "The Urban West: The Evolution of Prairie Towns to 1930" (1979) 4:2 Prairie Forum 235 at 237.

16

17

18

19

20

P.C. 1655. See Orders in Council, supra note 2 (No. 12, 1890) at 305.

J.B. Hedges, Building the Canadian West (New York: Macmillan, 1938) at 38.

Canada, House of Commons, Hansard, May 5, 1890, at 4429.

Forty-six leases were issued covering an area in excess of two million acres: Order in Council 11 April 1882 P.C. 722. See Orders in Council, supra note 2 (No. 4, 1882) at 135.

Supra note 18 at $4424-4425$. 
Sir John A. Macdonald. ... It is of great importance that the flow of capital and the immigration of gentlemen from England, who have taken a fancy to that country and are spending large sums of money in ranches, raising cattle and horses, should not be checked, as it will pretty soon if means of transport are not furnished for the cattle; and I am therefore extremely anxious that this road should be built as soon as possible.

Ironically the southern branch of the $\mathrm{C} \& \mathrm{E}$, while serving the large cattle ranches, also opened this area to settlement and exacerbated an existing confrontation between ranchers, who held leases from the Dominion, and settlers, who settled or squatted within the ranching leaseholds. ${ }^{21}$ As settlement encroached on the large ranching leases, the ranchers sought to secure their tenure by buying lands from the $\mathrm{C} \& \mathrm{E}:^{.22}$

As a group, cattlemen retained their dominant position in the southwestern countryside after 1896 simply by transferring their operations to the largest deeded holdings in the North-West Territories through purchase of great blocks of their former leases from the new Calgary and Edmonton Railway at a dollar fifty per acre.

Despite this initiative, settlement within the ranching leaseholds eventually consumed many of the large ranches which were such a feature of the District of Alberta in the 1880s and 1890s. By 1904 "the last gaps were filled in the band of settlement that stretched from Calgary south to Ft. Macleod along the old cattle trail that marked the division between the western foothills and the open eastern range. ${ }^{123}$

The first effort to formally select the land subsidy of the C \& $\mathrm{E}$ took place on November 19, 1891. The government adopted an Order in Council which identified some 841,309 acres of land which the railway had agreed to select as a part of its land subsidy; and which also created C \& E reserves of 679,331 acres from which additional lands could be selected. ${ }^{24}$ The legal descriptions of these lands were listed in schedules to the Order in Council. The land selected by the railway fell generally into three large blocks. The first block included lands on either side of the northern branch of the $C \& E$, between the northern boundary of the CPR main line reserve (north of the present town of Airdrie) and the southern boundary of the CPR northern reserve (near Innisfail). The second block included lands along either side of the southern branch of the $C \& E$ from the southern boundary of the CPR main line reserve (south of the present town of Okotoks) to Fort Macleod, including odd numbered sections throughout the Turner Valley area. The third block included lands along the first tiers of townships along the International boundary including an area between the Peigan and Blood Indian reserves.

$21 \quad$ D.H. Breen, The Canadian Prairie West and the Ranching Frontier 1874-1924 (Toronto: University of Toronto Press, 1983) at 70-77. Some ranchers were destroying the homes of settlers located inside the ranching leaseholds.

22 Ibid. at 77. See also: Martin, supra note 9 at 181: "In locating its land grant from the government, the Calgary and Edmonton Railway secured the cooperation of many of the largest leaseholders of grazing lands for a scheme which resulted in the mutual advantage of all three interests concerned. The Company undertook to sell their land at nominal prices ranging from $\$ 1$ to $\$ 1.50$ per acre."

23 Breen, ibid. at 127.

24 Order in Council November 19, 1891 P.C. 2787. See Orders in Council, supra note 2 (No. 13, 1891) at 571 . 
The Order in Council noted that there were about 500,000 acres of land in the vicinity of the $\mathrm{C} \& \mathrm{E}$ line which were held by ranchers under grazing leases. The government offered the Railway "the first right to the odd numbered sections" in these leased areas in the event that the leases were cancelled.

From time to time the Dominion set aside further reserves for the $C \& E$ and the Railway selected its land from these reserves by submitting lists of lands which it agreed to accept as a part of its land subsidy. The Dominion government approved the selection by issuing Orders in Council which listed the legal descriptions of the specific lands selected. An Order in Council of November 27, 1894 identified 125,222 acres of lands which the Railway had agreed to select as a part of its land subsidy. An Order in Council of October 16, 1895 identified a further 215,474 acres. On December 13, 1897, a further 140,852 acres were selected. On February 10, 1899, a further 8,960 acres. On August 17, $1900,13,576$ acres. On December 17, 1904, the remainder of the land subsidy was selected. ${ }^{25}$ The vast majority of these lands were selected as odd-numbered sections although a few even numbered sections in some townships were also selected. ${ }^{26}$ Lands which had formerly been a part of the Cochrane Ranch, the Stewart Ranch and the Walrond Ranch were also selected by the C \& E, as were some lands which had at one time been set aside by the Dominion as stock watering reserves. In the final result the $\mathrm{C}$ \& E located a significant part of its land subsidy in western and southern Alberta, particularly beside the foothills of the Rocky Mountains and along the first tiers of townships running along the international boundary with the United States.

\title{
III. MINES AND MINERALS
}

There are good indications of petroleum there, over a large area, which will make this country eventually of very considerable value.

Hansard, May 5, 1890, p. 4424

\begin{abstract}
Now, there are in the North-West Territories considerable sources of revenue in the mines, if a proper policy is adopted in regard to them. I never could understand why we should part with the fee in the mines as well as in the soil in that country.... Why should the Crown not reserve these mineral beds as a source of revenue to the Provinces which are to be established there in the future?"
\end{abstract}

Hansard, May 5, 1890, p. 4434

The organizers of the $C$ \& $E$ wanted the Railway's land subsidy to include mines and minerals. There may have been communications on this point prior to 1890 between Edgar Dewdney, Minister of the Interior in the Dominion government, and James Ross, the main 
contractor for the C \& $\mathrm{E}$ and a leading member of its organizing syndicate. ${ }^{27}$ Nevertheless the Dominion government took the position as early as 1890 , immediately after incorporation of the $\mathrm{C} \& \mathrm{E}$, that any land subsidy would not include mines and minerals. The Dominion's legal position was that all legislated railway land subsidies after $1887 / 1889$ were subject to Orders in Council dated October 31, 1887 and September 17, 1889.

The Order of October 31, 1887 applied only to Dominion Lands west of the Third Meridian, and provided simply:

All patents from the Crown ... shall reserve to Her Majesty, Her Successors and Assigns forever, all mines and minerals which may be found to exist within, upon, or under such lands, together with the full power to work the same.

This Order was not published in the Canada Gazette, and so was not duly promulgated into law, but a subsequent $A c t$ in $1894^{28}$ purported to give retroactive legal effect to the Order despite lack of publication.

In any event the Order in Council of September 17, 1889, also applied to the District of Alberta, N.W.T. This Order established regulations with the long title of "Regulations for the sale, settlement, use and occupation of Dominion Lands in Manitoba and the North West Territories" [the "Dominion Lands Regulations"]. ${ }^{29}$ Section 8 of the Dominion Lands Regulations provided:

\begin{abstract}
All patents from the Crown for lands in Manitoba and the North-West Territories, shall reserve to Her Majesty, Her Successors and Assigns forever, all mines and minerals which may be found to exist within, upon or under such lands, together with full power to work the same, and for this purpose to enter upon, and use or occupy the said lands or so much thereof and to such an extent as may be necessary for the effectual working of the said minerals, or the mines, pits, seams and veins containing the same, except in the case of patents for lands which have already been sold or disposed of for valuable consideration, or for lands which have been entered as homesteads before the date upon which these regulations came into force.
\end{abstract}

The Dominion maintained that this Order in Council, duly promulgated, certainly applied to the lands comprising the land subsidy to the $\mathrm{C} \& \mathrm{E}$.

On May 20, 1890 an official with the Department of the Interior wrote to the $\mathrm{C} \& \mathrm{E}$ and specifically drew its attention to the provisions of the Order in Council of October $31,1887 .{ }^{30}$ On July 6,1892 the Secretary of the Department of the Interior outlined the 
federal position in a letter to Osler Hammond \& Nanton, a partnership of land and financial brokers who were also leading members of the syndicate which organized the $\mathrm{C} \& \mathrm{E}:{ }^{31}$

Gentlemen - Referring to my letter to you of the 27th of May last, and previous correspondence with respect to the reservation of minerals in patents issued to the Calgary and Edmonton Railway Company for their land grant, or for lands acquired by them for townsite purposes, I find, on looking up the records, that an opinion was given on this point by the Department of Justice, on the 17th of June, 1891, to the effect that the grant to the Company having been made subsequent to the Order in Council of the 17th of September, 1889 ... your Company is only entitled to the surface rights in the land grant.

The C \& E did not accept the government position and the dispute went unresolved for over a decade.

On April 12, 1901 both the C \& E and the Calgary and Edmonton Land Company executed a formal request for the issue of patent for the SW 1/4-23-7-2-W5. On May 30, 1901 these requests were sent to the government. ${ }^{32}$ The companies specifically requested that the patent issue "without reservation of minerals, except gold or silver. ${ }^{133}$ The Dominion replied that the patent, if issued, would have a clause "reserving unto Her Majesty ... all mines and minerals, and the right to work the same. ${ }^{134}$

On October 8, 1901 the Calgary and Edmonton Railway Company and the Calgary and Edmonton Land Company prepared a Petition of Right for the Exchequer Court of Canada. ${ }^{35}$ The suppliants wanted the Court to direct that they were entitled to mines and minerals in the disputed quarter section, to issue a declaration that all future land subsidy patents should be issued without the reservation and to issue a further direction that patents previously issued with the reservation should be rectified.

The Exchequer Court of Canada, predecessor to the Federal Court of Canada, had jurisdiction to receive a Petition of Right advancing a claim against the Dominion government. The Dominion agreed that the case should go forward as a test case. The immediate issue was whether the land subsidy for the C \& E, 1,888,448 acres, was limited to the surface of the land, or whether it included both surface rights and mineral rights. The Calgary and Edmonton Land Company was described simply as "having an interest in the [C \& E] lands"36 and the Dominion agreed it was a proper party to the action.

Ibid. at 40 exhibit 13, letter dated July 6, 1892 from John R. Hall to Osler Hammond \& Nanton. Ibid. at 50-51, Exhibits 21, 22 and 23.

Gold and silver were specifically reserved to the Crown by the Dominion Lands Act, R.S.C. 1886, c. 54, s. 48.

Supra note 5, Privy Council, Appellant's Case, paragraph 15.

It would seem that at this time the petitioners had obtained a report dated July 13, 1901 from a land inspector, Mr. Dodds, referring specifically to oil beneath some of the $\mathrm{C} \& \mathrm{E}$ lands. This report included a bottle of oil sent as a sample. See: Provincial Archives of Alberta, accession 87.246, box 46, Robert James Stuart v. Calgary and Edmonton Railway Company et al., Appeal Book, Transcript of evidence at trial.

Supra note 5, Privy Council, Appellant's Case, paragraph 3. 
The case came on for hearing before the Exchequer Court sitting in Ottawa. The Suppliants were represented by Mr. Hellmuth of the law firm Kingsmill Torrance Hellmuth \& Saunders. His main arguments were that the Dominion Lands Regulations did not apply to subsidy lands granted to the $C \& E$ by special legislation, and, second, that the Regulations were in any event ultra vires.

On November 10, 1902, the Court rendered judgment. ${ }^{37}$ Mr. Justice Burbidge concluded that the $C \& E$ land subsidy was subject to a reservation of minerals in favour of the Crown. In reaching his conclusion he found it unnecessary to rely on the Order in Council of October 31, 1887, since in any event the Order of September 17, 1889 was in force when the legislation authorizing the C \& E land subsidy was enacted. He found

...great force in the argument that when Parliament grants a subsidy in Dominion Lands in aid of the construction of a railway, and nothing more is stated, that must mean a grant under ordinary conditions and subject to existing regulations respecting the land. There is nothing to indicate any intention in the present case to grant lands containing coal or other minerals in aid of the construction of the Railway ... or to give the companies more than they would have acquired had they purchased the lands for money instead of earning them by constructing such railways.

He also found that the Order was intra vires the Dominion, being supported by two provisions of the Dominion Lands Act. He gave judgment for the Crown.

The Suppliants appealed to the Supreme Court of Canada. On consent of the parties the appeal was heard by a panel of four, Chief Justice Sir Elzear Taschereau and Justices Girouard, Davis and Armour. Mr. Hellmuth represented the Appellants. The Court delivered its ruling on April 29, 1903. The panel was equally divided and, in the result, the judgment of the Exchequer Court was affirmed. ${ }^{38}$

Chief Justice Taschereau, with Justice Girouard concurring, would have allowed the appeal because the Order in Council of September 17, 1889 did not apply to a special Parliamentary grant of lands. They found that the statute authorizing a land subsidy to the C \& E was subject only to the Orders in Council made in respect of the land subsidy specifically and was not subject to pre-existing Orders in Council of general application. Justice Armour, with Justice Davies concurring, would have dismissed the appeal. They found that section 8 of the Order in Council of September 17, 1889 was intra vires under s. 90(h) of the Dominion Lands Act and was a part of the general law. They considered that the legislation which subsequently authorized a land subsidy to the $C \& E$ was itself subject to the general law. Limited v. His Majesty the King (1902) 8 Ex.C.R. 83.

38 The Calgary and Edmonton Railway Company and the Calgary and Edmonton Land Company v. The King (1903), 23 S.C.R. 673. The reasons for judgment are found in The Calgary and Edmonton Railway Company and the Calgary and Edmonton Land Company v. The King Privy Council, Record of Proceedings at 88-92. 
The Suppliants sought leave to appeal to the Judicial Committee of the Privy Council. Leave was granted on July 17, 1903. The appeal was heard before a panel consisting of Lord MacNaughten, Lord Davey, Lord Robertson, Lord Lindley and Sir Arthur Wilson. The Appellants were represented by Mr. Hellmuth and his partner Mr. Saunders.

On August 5, 1904, Lord Lindley delivered the unanimous judgment of the Judicial Committee. ${ }^{39}$ The Privy Council, in a short judgment covering four pages in the Appeal Cases, granted the appeal with costs. The matter of rectification of existing titles was remitted back to the Exchequer Court. ${ }^{40}$

The Privy Council judgment rested on a single, critical distinction - that the C \& E land grant was a subsidy and not a sale.

In considering the Dominion Lands Act and the Regulations of 1889 , the fact that the lands to be granted to the railway are to be granted as a subsidy, i.e. by way of bounty and not by way of sale, is all important. The enactments and regulations relating to Crown lands reserved for sale, or homesteads, have no application to the lands reserved for the totally different purpose of granting land by way of subsidies for public works.

The Privy Council concurred with the reasoning of the Chief Justice in the Supreme Court of Canada, that a special Parliamentary grant of lands to the $C \& E$ was not subject to pre-existing enactments and regulations relating to Crown lands reserved for sale or homesteads. In a further comment, Lord Lindley stated that the 1889 Dominion Lands Regulations "are themselves not so framed as to apply to such grants." He stated that the 1887 Order in Council "was never duly promulgated" and that the "it was conceded before their Lordships that this order should be disregarded."

The ratio of the Privy Council decision extended beyond the C \& E land subsidy because the legislation creating the $C \& E$ subsidy was virtually identical in form to other legislated subsidies to other railways. The decision therefore applied to all of the legislated railway subsidies enacted after $1887 .^{41}$ The practical result was that every land subsidy under the federal railway land grant system in Western Canada alienated mines and minerals from the Crown.

The enormous significance of the decision was considered by two historians, James Hedges and Chester Martin, who briefly discussed the C \& E land subsidy in the context of a broader study of Dominion railway policy. Although both made small errors of

\section{Supra note 5.}

In the years before the decision of the Privy Council the Dominion had sold some of the mineral estate it had reserved. The parties to the litigation had agreed that if the final outcome of the litigation was favourable to the suppliants the Dominion would pay over to them all of the proceeds of these sales in final satisfaction of their claim relating to these lands. On May 21, 1906 an Order in Council was issued authorizing the payment of $\$ 38,013.07$ in cash to the $C \& E$, being the funds realized from the sale of mineral estate in the subsidy lands.

Provincial Archives of Alberta, accession 84.314, letter dated November 16, 1904 from E.L. Newcombe, Deputy Minister of Justice, to the Secretary of the Department of the Interior. 
historical fact, ${ }^{42}$ their general conclusions are valid. Hedges concluded that the Privy Council decision "enunciated a principle of far-reaching importance" while Martin described the case as "a notable 'leading case' of general application to the whole Canadian system of contemporary railway land subsidies" ${ }^{\prime 33}$ and wrote:

Throughout the whole range of the Dominion railway land grant system, therefore, both surface and mineral rights (other than gold and silver) have come to be recognized in an area almost as large as England - more than $31,750,000$ acres - in the attempt to build the railways of a frontier community by means of the land subsidy through which they had to pass. ${ }^{44}$

The enduring historical effect of the Privy Council decision was the creation of millions of acres of private mineral title in Western Canada.

A legal scholar has written that many Privy Council decisions in the early years of this century "were short and not well thought out." ${ }^{145}$ The Privy Council judgment was certainly brief in length. Was it well thought out?

The Dominion had relied on the broad application of the ordinary words of section 8 of the Dominion Lands Regulations: "All patents from the Crown ... shall reserve to Her Majesty ... all mines and minerals...". The Privy Council limited the application of these words by restricting the scope of the regulations to situations involving sale or homesteads. This narrow interpretation of the scope of the Regulations seems to be drawn from the long title of the Regulations (quoted above); and from the heading "Sale of Dominion Lands" which appeared immediately before Section 8 of the Regulations. At the time of the Privy Council decision there was a trend in statutory interpretation to utilize headings to limit or explain the operation of a statute. ${ }^{46}$ In 1898, Lord Lindley, then in the Court of Appeal, held that the title of a statute held "the key to the enactment" then before the Court. ${ }^{47}$ Today the trend in statutory interpretation has changed

Hedges concluded that all of the C \& E land subsidy was conveyed to the Calgary and Edmonton Land Company except for the lands held by the Dominion as an indemnity under the transportation contract, overlooking the fact that Ross held 173,768 acres and Osler Hammond \& Nanton held a further 100,000 acres. Chester Martin's account is marked by a number of errors. He mistakenly described the Calgary and Edmonton Land Company as a subsidiary of the C \& E. He suggested that the railway was compelled to take much semi-arid land in complete townships, while the legal descriptions of the land actually selected by the $C \& E$ indicate that the vast majority of lands were actually selected in alternate sections. Hedges, The Federal Railway Land Subsidy Policy of Canada, (Cambridge: Harvard Univ. Press, 1934) at 116; Martin, supra note 9 at 64. Martin, ibid. at 65. W.I. Jennings, "Constitutional Interpretation: The Experience of Canada" 15 Harvard L.R. 1 at 16. W.F. Craies, A Treatise on Statute Law, 2d ed. (London: Stevens and Haynes, 1911) at 211. The leading case seems to have been Eastern Counties Railway v. Marriage where Channell B. stated: "These various headings are not to be treated as if they were marginal notes... They constitute an important part of the Act itself and may be read not only as explaining the sections which immediately follow them ... but as affording ... a better key to the construction of the sections which follow...". See also: Craies on Statute Law, 7th ed. (London: Sweet \& Maxwell, 1971) at 207 [hereinafter Craies]. 
somewhat and, in practice, Courts look first for ambiguity in the plain language of a statute before using headings to assist in the task of construction. ${ }^{48}$

The Privy Council's decision to disregard the Order in Council of 1887 is problematic. Modern legal writers hold that the 1887 Order in Council was effective in reserving mines and minerals in homestead dispositions. ${ }^{49}$ Paradoxically, then, the 1887 Order in Council is disregarded in relation to railway land subsidies but the same Order is cited as effective in reserving mines and minerals in homestead dispositions. On balance it is disappointing that the Privy Council did not consider the attempt by Parliament in 1894 (outlined above) to give the 1887 Order in Council retroactive validity. In modern times this would give rise to an issue of Crown obligation to parties who acquired rights before the retroactive application. ${ }^{50}$ The terms of the 1887 Order in Council were not limited by any headings or titles and, had the Privy Council considered this Order, it could have been more difficult for the Court to limit the scope of its application.

The Privy Council did not have to consider the validity of section 8 of the 1889 Dominion Lands Regulations because its judgment rested on the ground that the regulation did not in any event apply to the C \& E subsidy. The lower Courts had ruled in favour of the validity of the Regulation. This section was judicially considered many years later and was again found to be intra vires. ${ }^{51}$

It is unfortunate that the Privy Council did not consider the validity of section 8 of the Dominion Lands Regulations. The parties to the litigation agreed that gold and silver were not included in the railway land subsidy by virtue of the Dominion Lands Act. ${ }^{52}$ It is reasonably clear that the Privy Council agreed that this general provision of the Dominion Lands Act applied to railway land subsidies even though these subsidies were expressed in a special Parliamentary grant. Yet this is not consistent with Lord Lindley's comment that "[t]he enactments and regulations relating to Crown lands reserved for sale, or homesteads, have no application to the lands reserved for the totally different purpose of granting land by way of subsidies for public works." If a general provision of the Dominion Lands Act dealing with reservation of gold and silver applied to the C \& E land subsidy, it is not unreasonable to assume that a general provision of the Dominion Lands Regulations validly promulgated under the authority of the Dominion Lands Act and dealing with reservation of base minerals could also apply to the subsidy.

Finally, though, it should be recognized that Parliament had the opportunity to make the $C \&$ E land subsidy expressly subject to a reservation of mines and minerals in favour of the Crown, yet none of the Acts or Orders in Council relating to the $C \& E$ land

Craies, supra note 46 at 209.

Bennett Jones Verchere (Barristers and Solicitors) and N. Bankes, Canadian Oil and Gas, 2d ed., (Toronto: Butterworths, 1991) at par. 27.

See: R.J. Harrison, "The Legal Character of Petroleum Licences" 58 Can. Bar Rev. 485; and A.R. Thompson, "Sovereignty and Natural Resources" 4 U.B.C. L.R. 161.

Starley v. New McDougall-Segur Oil Co., [1927] 3 D.L.R. 428 and 811 (Alta.S.C.); and Creighton

v. United Oils, [1927] 3 D.L.R. 432 and 804 (Alta S.C.).

R.S.C. 1886 c. 54 s. 48. 
subsidy mention mines and minerals. All were adopted after the 1889 Dominion Lands Regulations were in force and it would have been a simple matter to incorporate the provisions of section 8 of those Regulations into the C \& E subsidy legislation. Instead the application of the Regulations to the C \& E subsidy was left as a matter of interpretation, a matter of construction. On this point of law reasonable minds could, and did, reach different conclusions.

\section{TAXATION}

So long as they are Crown lands they are exempt from taxation, but when they are conveyed from the Crown to the company they are no longer exempt.

Prime Minister Sir John A. Macdonald, Hansard, May 5, 1890, p. 4430.

Well before 1905, the policy of subsidizing railway construction by land grants had been discontinued but the process of selecting these lands so earned, and the after-math of tax exemption, remained for many years to vex the growing communities in the West.

Report of the Royal Commission on the Natural Resources of Alberta

(Ottawa: King's Printer, 1935) at 10.

The C \& E assigned its interest in much of its land grant to its bankers and to two of its directors, individuals who in turn transferred their interests to the Calgary and Edmonton Land Company. So the Calgary and Edmonton Land Company became entitled to obtain patent directly from the Dominion, and the practice was for the it to file "some form of deed with the government."153 The Dominion would not issue the patent, however, until the assignee paid the costs of survey. By this mechanism, by delaying the issue of patent until the survey expenses were paid, the C \& E and the Calgary and Edmonton Land Company avoided taxation on the lands or on their interests in the lands. The legal theory behind the tax avoidance was that prior to the issue of the patent the land was land 'belonging to' the Crown in right of the Dominion, within the meaning of sec. 125 of the B.N.A. Act, and was exempt from taxation. This theory was tested before the Courts when the Calgary and Edmonton Land Company was assessed for taxation under the Local Improvement Act, S.A. 1907, c. 11.

The material facts before the Courts were straightforward. In 1906, the Calgary and Edmonton Land Company was assessed for tax arrears relating to NE 1/4-3-16-2-W5, some distance south of Turner Valley, Alberta. This specific property was included in the list of lands which the $C \& E$ had agreed to select as a part of its land subsidy pursuant to the Order in Council of November 18, 1891 (discussed above). In 1902, the Calgary and Edmonton Land Company obtained a deed from the C \& E for some 49,000 acres of the land subsidy, including this quarter section. Patent was not issued until June 19, 1907, when Osler Hammond \& Nanton paid the survey fees. The Calgary and Edmonton Land Company was assessed for tax in 1906, after the deed was executed but before patent was 
issued. The Local Improvement Act provided for "tax ... upon every owner or occupant in the district for all land owned or occupied by him." The term 'Owner' was broadly defined in the legislation as any person who has any right, title or estate whatever in the land. The assessment of the Tax Commissioner of the Department of Public Works was confirmed by Chief Justice Sifton.

The Calgary and Edmonton Land Company appealed to the Supreme Court of Alberta (en banc) and the appeal was argued in December of 1909 before Justices Harvey, Beck and Stuart sitting in Calgary. ${ }^{54}$ Mr. Bennett K.C., of the law firm Lougheed, Bennett \& Company, argued for the Appellants. He argued that until patent issued the land remained Dominion land, sheltered from provincial taxation by section 125 of the British North America Act; and that if the land were taxed before patent the grant would not be a "free grant" as provided in the Statutes of Canada (1890) An Act to authorize the granting of subsidies in Land to certain Railway Companies.

Judgment of the Court was delivered on December 24, 1909. Justices Stuart and Harvey concurred in the judgment of Justice Beck. The argument that the land was land "belonging to" the Dominion with s. 125 of the British North America Act was rejected on the basis that "the whole beneficial interest in the land was vested in the company, and only the bare legal estate remained in the Crown." Although the exact moment at which the beneficial interest vested was not identified, Justice Beck held that "an officer of the company could, long prior to patent, with an absolutely clear conscience and without hesitation, have sworn simpliciter that the land in question was land belonging to the company." He suggested that this vesting arose, in any event, no later than "the moment it undertook to deal with it as its own" which "it did by the [deed] of 13 December 1902." He had no doubt that the Company could have enforced its absolute right to a patent by petition of right.

A concurring judgment was written by Justice Stuart, who held that the Appellant's interest in the land was "the whole beneficial interest, leaving the Crown a bare trustee holding the bare legal estate, whose transfer to the appellants subsequently was a mere matter of form." He described the obligation to pay survey fees as "merely an encumbrance on the company's equitable interest." He agreed that the Land Company was entitled to patent "long before the tax was imposed" but did not specify the exact date on which the entitlement had vested.

The Calgary and Edmonton Land Company applied for leave to appeal to the Supreme Court of Canada. The case was advanced as a significant test case and on March 3, 1910, leave was granted by the Chief Justice of the Court "because of the magnitude of the interests involved." 55 The case was described as "a test case to determine the liability to provincial assessment of lands comprised in the land subsidy which had been fully earned but which had not been actually patented." ${ }^{\text {s6 }}$

so Ibid. at 188. 
In the meantime, however, additional lands had been assessed for taxation prior to the issue of patent and the returns had been placed before the Alberta Supreme Court in Lethbridge, Macleod and Calgary, for confirmation in accordance with the Local Improvements Act. Osler Hammond \& Nanton reached an agreement with the Attorney General of Alberta under which all of these proceedings were stayed pending the final outcome of the litigation. ${ }^{57}$

The Supreme Court of Canada heard argument on May 18 and 19, 1911, and rendered judgment on October 3. The Court, in a series of individual judgments, was unanimous in agreeing to dismiss the appeal. Justice Davies delivered the leading judgment. With respect to the argument that "free grant" lands could not be subject to taxation, he reasoned that the phrase: $:^{.8}$

...meant free from any of the customary charges made by the Government in selling its vacant land to settlers or others, and from any charges of any kind by or on behalf of the Crown excepting those expressly mentioned for survey fees. It could not ... be intended to exempt the beneficial interest of the railway company in the lands from liability to local taxation which it otherwise would be subject to after it came into existence, and before patent issued.

He agreed that the Dominion held only the bare legal title to the land after the C \& E had constructed its railway line and had earned the right to patent for the land subsidy subject to payment of survey fees. He found that the C \& E had transferred this "equitable title" to the Calgary and Edmonton Land Company by the deed of 1902, and the Local Improvement Act applied to this interest: ${ }^{59}$

The whole beneficial interest having passed to the company and the bare legal estate remaining in the Crown the land no longer can be said to be land belonging to Canada within the meaning of the section [125 of the B.N.A. Act].

In separate reasons, Justices Anglin and Idlington agreed, on the evidence before them, that the C \& E had transferred its interest in the property to the Calgary and Edmonton Land Company by the deed of $1902 .^{60}$

On August 19, 1912, the solicitors for the Calgary and Edmonton Land Company wrote that they had been instructed not to proceed with a further appeal to the Privy Council. ${ }^{61}$ The Calgary and Edmonton Land Company was prepared to pay taxes on the land which was the subject of the litigation and for all other lands in the same position.

Provincial Archives of Alberta, accession 66.166 file 630, letter dated March 31, 1911, from Munson, Allan Laird \& Davis to the Altorney General of Alberta.

Supra note 6 at 176.

lbid.

Ibid. at 184 per Idlington J., at 188 per Anglin J.

Provincial Archives of Alberta, accession 66.166 file 630, Letter dated August 19, 1912 from Munson

Allan Laird \& Davis to F.E. Clarry. 
Legal scholars recognized the ruling of the Supreme Court of Canada as an important constitutional decision of its day: "[t]he principle of the decision covers any beneficial interest, legally recognizable, in any person in land or property, notwithstanding that ... legal title still remains in the Crown; and therefore upholds provincial taxation of homestead and pre-emption interests. ${ }^{162}$ The decision was considered and approved by the Judicial Committee of the Privy Council in Smith v. Vermilion Hills Rural Council, which dealt with tax assessment of grazing leases on unpatented Crown lands in Saskatchewan. ${ }^{63}$ The decision was applied by the Supreme Court of Canada in Southern Alberta Land Co. v. Rural Municipality of McLean ${ }^{64}$ dealing with taxation of an interest in lands obtained for irrigation purposes; in Grand Trunk Pacific Railway v. The City of Calgary $^{65}$ dealing with unpatented lands where the purchase price had not yet been entirely paid; and in City of Vancouver v. Attorney General of Canada and Others ${ }^{66}$ dealing with assessment of railway land which the Crown had leased. A number of lower courts have also applied the case. ${ }^{67}$

There is one aspect of the case, however, which is not fully developed, and that is the exact moment at which the Calgary and Edmonton Land Company obtained its beneficial interest from the $\mathrm{C} \& \mathrm{E}$. Since the case went forward as an appeal from a tax assessment the material facts before the Courts were limited to the immediate circumstances surrounding the assessment. It was sufficient for these purposes to consider that the interest was obtained by the deed of 1902 . There are, however, additional facts relating to the land dealings between the $\mathrm{C} \& \mathrm{E}$ and the Calgary and Edmonton Land Company, facts not before the Courts, which suggest that the beneficial interest had been acquired at least as early as 1895 .

In 1890 , the $C \& E$ needed initial financing for the construction of its railway line. Early in June of 1890 , before the C \& $E$ had even begun to build its railway line, the C $\& \mathrm{E}$ obtained this financing from the London banking firm of Morton Rose \& Co. ["the bankers"]. ${ }^{68}$ The essence of the arrangements between the $C \& E$ and the bankers were that the bankers provided a capital investment, $\$ 1,436,000$, and received in return 800,000

W.H.P. Clement, The Law of the Canadian Constitution (Toronto: Carswell, 1916) at 644. See also: A.S. Abel \& J.I. Laskin, eds., Laskin's Canadian Constitutional Law, 4th ed. (Toronto: Carswell, 1975) at 743.

[1916] 2 A.C. 569 at $573-4$.

(1916), 53 S.C.R. 151.

(1917), 55 S.C.R. 103.

[1944] S.C.R. 23.

Including Manitoba Provincial Municipal Assessor v. Harrison, [1971] 3 W.W.R. 735 (Man Q.B.). Morton Rose \& Co. was established as a London branch of Morton Bliss \& Co., a successful private bank based in New York and founded by Levi P. Morton. Morton was the republican candidate for vice-president in 1888 and served as Governor of New York from 1894 until 1896. Sir John Rose, a native of Scotland, was the founding member of Morton Rose \& Co. Sir John Rose had a very successful law practice and political career in Canada before relocating to London in 1869 where he pursued a new career as an investment banker. His Canadian accomplishments, apart from his Montreal law practice, included service as the British commissioner for settlement of claims associated with the Oregon Treaty and election to Parliament, where he served in the Conservative cabinet from 1867 until 1869. Rose managed the London firm until from 1869 until 1876 when he stepped aside in favour of his second son Charles Day Rose. 
acres of the land subsidy which the $C \& E$ would earn by building its line.$^{69}$ At the same time the C \& E gave two of its key Canadian directors ["the Canadian directors"] a further 407,278 acres of the $C \& E$ land subsidy as a reward for their efforts in organizing the $\mathrm{C} \& \mathrm{E}$, in obtaining the necessary financing from the bankers and in later arranging public sales of $C \& E$ bonds in London.

In 1891, as the $C \& E$ was building the northern branch of its line but before the $C$ \& $E$ had earned any part of its land subsidy by finishing the branch, the first Calgary and Edmonton Land Company was incorporated to hold the interests of the bankers and the Canadian directors. The Calgary and Edmonton Land Company acquired these interests through two pre-incorporation agreements dated May 21, 1891, one agreement with Morton Rose \& Co. and the other with the Canadian directors. ${ }^{70}$ Both agreements were drafted in similar terms. The vendors were described as "the absolute owners free from incumbrances of ... lands ... forming part of the lands granted in aid of the construction of the Calgary and Edmonton Railway" (even though the land subsidy had not yet been earned by the $C \& E$ ). The terms of the agreements were that the vendors would sell their interests in the land "free from all mortgage charges or encumbrances other that the terms and conditions of the patents or orders in council granting or agreeing to grant the same." Consideration for sale was the allotment to the vendors or their nominees of fully paid up shares in the Calgary and Edmonton Land Company. On May 22, 1891, the Calgary and Edmonton Land Company was incorporated in London pursuant to the English Companies Act of $1862^{71}$ and on June 8, 1891, the Calgary and Edmonton Land Company duly adopted the two pre-incorporation agreements. ${ }^{72}$ The pre-incorporation agreements were filed with the Registrar of Companies in London thereby avoiding a potential call on the shares. ${ }^{73}$ This arrangement was, in essence, a simple exchange of a significant part of the $\mathrm{C} \& \mathrm{E}$ land subsidy for fully paid up shares in the Calgary and Edmonton Land Company.

On December 23, 1895, after the C \& E had completed the construction of its line and thereby earned the right to select its entire land subsidy, an agreement was signed between the $C \& E$ and the Calgary and Edmonton Land Company. ${ }^{74}$ For a consideration of one dollar the $C$ \& $E$ conveyed to the Calgary Edmonton Land Company all of its interest or expected interest in 1,207,278 acres of its land subsidy. The C \& E agreed to use due diligence to select lands and to convey the lands selected to the Calgary and Edmonton Land Company, free of all liens and encumbrances except the payment of survey fees imposed by Order in Council. At this time, and for several years following, a large portion of the $C \& E$ land subsidy remained unselected.

Public Records Office, London, BT31/5067/34064/XC08571.

Ibid.

T. Skinner, The Stock Exchange Yearbook for 1923 (London: Thomas Skinner and Co., 1923) at 994.

Supra note 69.

See: F. Gore-Browne \& W. Jordan, Handbook on the Formation, Management and Winding Up of Joint Stock Companies, 31 st ed. (London: Jordan \& Sons Ltd, 1911) at 170.

Supra note 69, Indenture between the Calgary and Edmonton Railway Company and the Calgary and Edmonton Land Company. 
On March 8, 1902, when a significant market demand for the C \& E land subsidy had begun to develop, a second Calgary and Edmonton Land Company Ltd. was incorporated in London. ${ }^{75}$ This second company acquired the assets of the first company of the same name including its rights to the majority of the $C \& E$ land subsidy. It was this second Calgary and Edmonton Land Company which disputed its liability to pay tax on its interest in NE 1/4-3-16-2-W5. There was a delay in the payment of survey fees and patent for the lands had still not issued when that specific property was assessed for tax arrears in 1906.

In the circumstances, then, reference to the deed of 1902 should be considered a convenient means of identifying the date on which the beneficial interest was obtained for the purposes of the decision, and should not be regarded as a definitive ruling on the date on which the beneficial interest was created. The Calgary and Edmonton Land Company obtained a definite entitlement to $1,207,278$ acres of the C \& E land subsidy at least as early as 1895 , and possibly as far back as 1891 .

\section{CONCLUSION}

Although there had never been much doubt in Canada as to the wisdom of using the land for the building of railways, there had been considerable uncertainty as to the best manner of using it.

James B. Hedges, Building the Canadian West (New York: The Macmillan Company, 1939) at 32.

The railway land subsidy policy of the Dominion government existed between 1881 and 1894. Federal legislation defined public subsidies for railway construction, primarily land subsidies and tax exemptions. The immediate effects of this policy, this public support of private enterprise, lasted well more than a decade after the final subsidy statute came into force. By building its railway line the C \& E had a profound impact on the history of Alberta. By providing an opportunity for judicial consideration of its specific subsidy legislation the $C \& E$ had an equally profound impact on the general Dominion scheme of subsidies to railways in Western Canada. By pursuing litigation, the $C \& E$ and the Calgary and Edmonton Land Company lost a lucrative tax avoidance strategy but gained, for itself and for other private citizens and corporations, enormous mineral wealth derived from the public estate.

The remaining narrative of historical events relating to the $C \& E$ land grant are quickly told. In 1903, the CPR purchased the C \& E and leased its line for 99 years. $^{76}$ By virtue of this acquisition the CPR obtained title to 407,402 acres of the C \& E land subsidy including mines and minerals. The second Calgary and Edmonton Land Company proceeded over time to sell surface rights in its share of the C \& E land subsidy, 96, Certificate of Incorporation under the Companies' Acts 1862 to 1900.

76 By a separate agreement concluded between the CPR and the $C \& E$ in 1890, the CPR operated over the $C \& E$ line immediately upon its completion. The $C \& E$ itself never pulled a car of its own over its line. 
$1,207,278$ acres, and reserved to itself mines and minerals in those lands. The remaining portion of the $\mathrm{C} \& \mathrm{E}$ land subsidy was divided between its key directors.

As it turned out the C \& E had selected as a part of its land subsidy every alternate odd-numbered section in much of the area near Turner Valley, Alberta. The Calgary and Edmonton Land Company had the rights to most of these lands. In 1914, a well known as Dingman No. 1 struck oil and gas in the area. This did not prove to be a commercially viable discovery because the limited drilling technology of the time did not allow for a deeper well to be drilled; but it did spark a brief speculative boom in nearby Calgary. In the autumn of 1924, though, another well known as Royalite No. 4 struck a productive horizon at a depth of 3,740 feet. An enduring natural gas and petroleum oil flow was discovered which, by 1925, made Alberta "the leading petroleum producing province of the Dominion. ${ }^{177}$ Over 45 wells were soon drilled near Turner Valley in an effort to explore the boundaries of the producing formation.

By 1929 this oil and gas exploration and development had significantly increased the value of the mineral holdings of the Calgary and Edmonton Land Company. In that year these mineral holdings were transferred from the Calgary and Edmonton Land Company in England to the Calgary and Edmonton Corporation Ltd., a Canadian company. ${ }^{78} \mathrm{~A}$ third Calgary and Edmonton Land Company was then incorporated in England to hold the surface rights which the second company of the same name had not yet sold, about 55,342 acres of surface rights of land in Alberta together with 132 townsite lots and some 59 acres of land set aside for subdivision as townsite lots. The third Calgary and Edmonton Land Company was finally struck off the corporate register in Alberta in 1984.

The Calgary and Edmonton Corporation Ltd. was active in the Turner Valley oil and gas fields after 1929 and was a significant independent operator in the Alberta oil patch after the Leduc discovery of 1947. By 1931, the Corporation's lands near Turner Valley included eleven producing wells with a total annual production of 219,618 barrels. Its success became dramatic after the Leduc discovery of 1947. By 1950, some 848,562 acres of mineral rights, 74 per cent of the Corporation's lands, were leased or were under option to lease. In 1955, the Calgary Herald described the Calgary and Edmonton Corporation Ltd. as "one of Alberta's three biggest holders of mineral lands." In 1968, the Calgary and Edmonton Corporation Ltd. was acquired by Canadian Superior Oils Ltd. ${ }^{79}$

G.S. Hume, "Turner Valley Oil Area, Alberta" in Canada, Department of Mines, Geological Survey, Summary Report 1926 Part B, preface and at 75.

On February 5, 1929, the Calgary and Edmonton Corporation Ltd. was federally incorporated in Canada. Shares in the new company were allotted only to the shareholders of the Calgary and Edmonton Land Company. The Calgary and Edmonton Land Company transferred its mineral assets in Alberta, over 1,150,000 acres, to the Calgary and Edmonton Corporation. On June 20, 1929, the Calgary and Edmonton Corporation issued a notice to its shareholders indicating that it would pursue a policy of leasing its mineral rights. Annual Reports of the Calgary and Edmonton Corporation Lid. can be found in the Glenbow Alberta Institute Archives accession M1540. 